\title{
CASUARIUS AUSTRALIS.
}

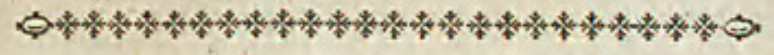

\section{CHARACTER GENERICUS.}

Rofrum depreffum, rectum, fubconicum.

Nares ovatæ.

Ale breviffimæ, volatui inutiles.

Femora in parte inferiore denudata.

Pedes tridactyli, digitis omnibus anticis.

Cauda nulla.

$$
\text { Lath. ind. orn. p. 664. }
$$

CHARACTER SPECIFICUS, $\Xi{ }^{c}$.

CASUARIUS FUSCUS, vertice inermi.

STRUTHIO CASUARIUS.

Lin. Syft. Nat. p. $26_{5}$.

CASUARIUS NOV Æ HOLLANDIE.

Lath. ind. orn. p. $66_{5}$.

Inter aves quas protulit ingens illa infula Nova $\mathrm{Hol}$ landia (ni continens potius appelletur) infignis eft qua in tabula depingitur Cafuarii fpecies; a communi feu Africana adeo difcrepans; ut dubitari non poffit illam penitus et revera diverfam effe. Magnitudine enim eft multo majori, alta interdum, ad minus, pedes feptem. Color imus cinereo-fufcus, fubtus pallidior. Caret caput galea feu crifta illa cornea, quæ fpeciem commu- 
nem diftinguit. Collum præterea loco rugofæ illius et rubræ cæruleæque cutis, et caruncularum quæ in Africana confpicuæ, pennis parvis veftitur, per quas ipfa cutis in hac parte leviter cærulea vix ac ne vix difcerni poffit. In apicibus alarum, quæ ad volandum inutiles, unguiculus eft incurvatus et acutus. Crura validiffima, nigricantia, et in parte poftica confpicue ferrata. Roftrum ejufdem fere coloris cum cruribus. 


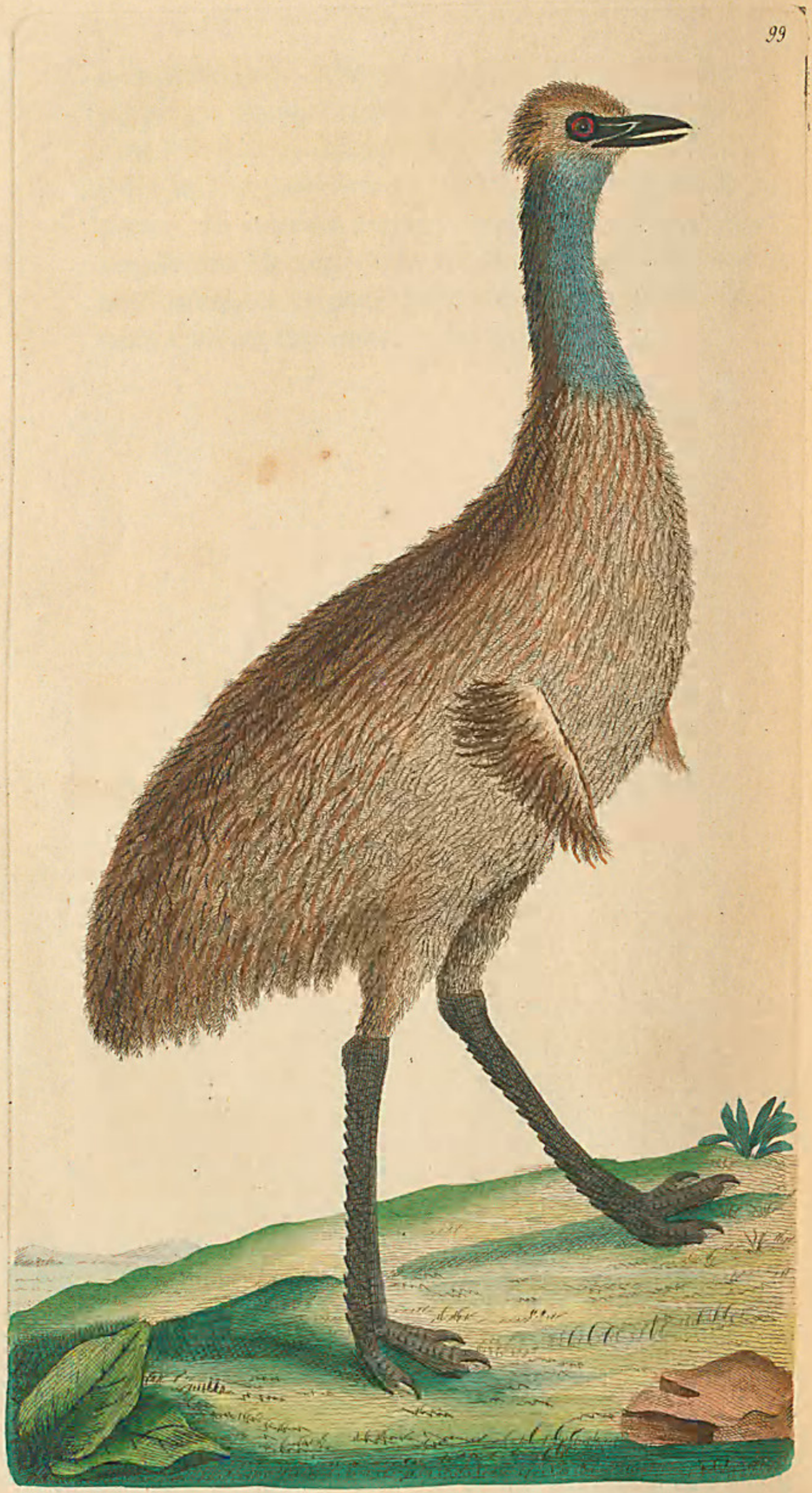




\section{SOUTHERN CASSOWARY.}

Q

GENERIC CHARACTER.

Bill depreffed, ftrait, nearly conical. Wings extremely fmall, and unfit for flight. Feet tridactylous, with all the toes ftanding forward.

\section{SPECIFIC CHARACTER, $\mathcal{E}^{2} \mathrm{C}$.}

DARK-BROWN CASSOWARY with unarmed head.

NEW-HOLLAND CASSOWARY.

White's Voyage, pl. 1. p. 129.

One of the mort remarkable birds which the continent of New Holland has yet afforded is a fpecies of Caffowary which differs from the common or African kind in fo many refpects as to leave no doubt of its being perfectly diftinct. In fize it is confiderably fuperior to the common Caffowary, having been feen of the height of at leaft feven feet. Its general colour is a fort of cinereous brown, fomewhat paler beneath. The head is deftitute of that horny creft which fo ftrikingly diftinguifhes the African fpecies; and the neck inftead of being furnifhed with a wrinkled longitudinal redand-blue fkin and wattles as in that bird, is covered $\mathrm{M}_{2}$ with 
with fmall feathers, through which the fkin, which is of a bluifh colour in that part, is juft vifible. The wings are perfectly ufelefs for flight, and at the tip of each is a fmall, tharp, crooked fpur or claw. The legs are very ftrong, of a blackifh colour, and of a ferrated appearance on the hinder part. The beak is of nearly the fame colour with the legs. 


\section{$2 \mathrm{BHL}$ Biodiversity Heritage Library}

Shaw, George. 1792. "The Southern Cassowary, Casuarius australis [PI. 99]." The Naturalist's Miscellany 3(XXXIII), https://doi.org/10.5962/p.304519.

View This Item Online: https://www.biodiversitylibrary.org/item/279090

DOI: https://doi.org/10.5962/p.304519

Permalink: https://www.biodiversitylibrary.org/partpdf/304519

\section{Holding Institution}

Museums Victoria

\section{Sponsored by}

Atlas of Living Australia

\section{Copyright \& Reuse}

Copyright Status: Public domain. The BHL considers that this work is no longer under copyright protection.

This document was created from content at the Biodiversity Heritage Library, the world's largest open access digital library for biodiversity literature and archives. Visit BHL at https://www.biodiversitylibrary.org. 